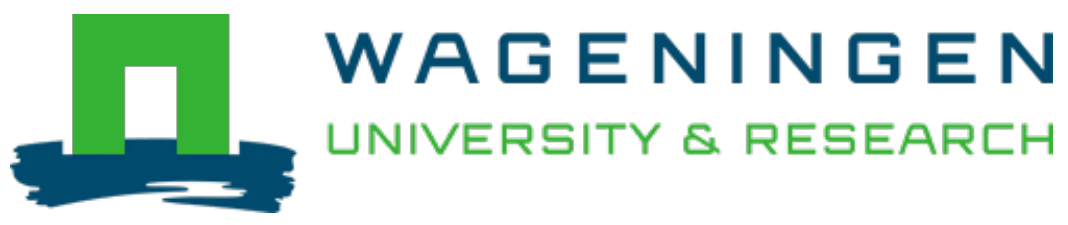

\title{
Mining for Mother Earth. Governmentalities, sacred waters and nature's rights in Ecuador
}

\section{Geoforum}

Valladares, Carolina; Boelens, R.A.

https://doi.org/10.1016/j.geoforum.2019.02.009

This publication is made publicly available in the institutional repository of Wageningen University and Research, under the terms of article $25 \mathrm{fa}$ of the Dutch Copyright Act, also known as the Amendment Taverne. This has been done with explicit consent by the author.

Article 25 fa states that the author of a short scientific work funded either wholly or partially by Dutch public funds is entitled to make that work publicly available for no consideration following a reasonable period of time after the work was first published, provided that clear reference is made to the source of the first publication of the work.

This publication is distributed under The Association of Universities in the Netherlands (VSNU) 'Article $25 \mathrm{fa}$ implementation' project. In this project research outputs of researchers employed by Dutch Universities that comply with the legal requirements of Article $25 \mathrm{fa}$ of the Dutch Copyright Act are distributed online and free of cost or other barriers in institutional repositories. Research outputs are distributed six months after their first online publication in the original published version and with proper attribution to the source of the original publication.

You are permitted to download and use the publication for personal purposes. All rights remain with the author(s) and / or copyright owner(s) of this work. Any use of the publication or parts of it other than authorised under article $25 \mathrm{fa}$ of the Dutch Copyright act is prohibited. Wageningen University \& Research and the author(s) of this publication shall not be held responsible or liable for any damages resulting from your (re)use of this publication.

For questions regarding the public availability of this publication please contact openscience.library@wur.nl 


\title{
Mining for Mother Earth. Governmentalities, sacred waters and nature's rights in Ecuador
}

\author{
Carolina Valladares $^{\mathrm{a}, *}$, Rutgerd Boelens ${ }^{\mathrm{a}, \mathrm{b}, \mathrm{c}, \mathrm{d}, 1}$ \\ ${ }^{\text {a }}$ Centre for Latin American Research and Documentation, University of Amsterdam, Amsterdam, the Netherlands \\ ${ }^{\mathrm{b}}$ Environmental Sciences Department, Wageningen University, Wageningen, the Netherlands \\ ${ }^{\mathrm{c}}$ Department Social Sciences, Pontificia Universidad Católica del Perú, Lima, Peru \\ ${ }^{\mathrm{d}}$ Faculty of Agricultural Sciences, Universidad Central del Ecuador, Quito, Ecuador
}

\section{A R T I C L E I N F O}

\section{Keywords:}

Mining

Cultural politics

Governmentality

Rights of nature

Ecuador

\begin{abstract}
A B S T R A C T
Getting public opinion to see 'mining' and 'Nature's Rights' as non-contradictory and even equivalent and harmonious, calls for far-reaching power strategies. Nature was entitled to rights by Ecuador's Constitution at about the same time that the Government began promoting mining as central to Ecuador's future. Building this equivalence to make 'mining mean nature', and materialize large-scale mining in the Quimsacocha páramo wetlands, the State and its institutions tested new tactics to manage territory, coined new imaginaries and subjectivities, and limited indigenous/rural political participation. In response, communities started to dispute these governmentality strategies through political practices that framed new meanings of territory and identity. They use formal political and legal arenas but, above all, their day-to-day practices. This article analyzes forms of power and counter-power in the Quimsacocha páramo mining conflict, through the four different, inter-related 'arts of government' (Foucault, 2008) and mutual strategies by promoters and detractors of extractive industry who, in apparent paradox, both appeal to Nature's Rights. We conclude that using Nature's Rights to promote mega-mining manifests the limitations of social and environmental rights recognition under neoliberal governance, and the tensions inherent in Nature's Rights themselves. However, anti-extraction struggles like Quimsacocha's critically make visible as well as challenge the development model and economic system that is implicit in the debate over Nature's Rights, inviting us to re-think the socio-natural order and foster more just, equitable alternatives.
\end{abstract}

\section{Introduction}

Just as environmental devastation approaches the point-of-no-return, and extractive industries are occupying the last frontiers, innovative environmental policies and guarantees for respecting Mother Earth, by the governments of Ecuador (2007-2017) and Bolivia (since 2006), seemed to offer a turnaround toward new forms of ecological democracy (Perreault and Valdivia, 2010; Escobar, 2010; Lalander \& Ospina, 2012; Radcliffe, 2012). However, while they suggest to strive for sustainable development, they often expanded extractive projects into protected zones and indigenous territories, using both subtle and coercive/authoritarian strategies for exerting State power (Arsel et al., 2016; Bebbington et al., 2010; Hogenboom 2012; Gudynas, 2010; Lu et al., 2017; Urkidi \& Walter, 2011; Veltmeyer, 2012).
In the specific case of Ecuador, the Government welcomed megamining accompanied by compensation policies and communicational strategies, re-interpreting constitutional guarantees (such as 'Good Living', 'Nature's Rights', pluri-nationality, and water as a human right) to neutralize conflicts. Nature's Rights, recognized in the Ecuadorian Constitution since 2008, ended up playing a dual role as a discourse enthusiastically embraced by both mining proponents and critics to support their respective views. Through an analysis of the Quimsacocha mining project (now known as Loma Larga Project) in the Ecuadorian highlands, this paper shows how Nature's Rights represent a tool of power and counter-power, subtly and boldly deployed in political-cultural strategies and practices.

In particular, the article aims to identify and grasp subtleties in State practices, discourses and strategies employed to materialize large-scale

\footnotetext{
*Corresponding author at: Centre for Latin American Research and Documentation, University of Amsterdam, Roetersstraat 33, 1018 WB Amsterdam, the Netherlands.

E-mail addresses: a.c.valladares@cedla.nl (C. Valladares), rutgerd.boelens@wur.nl (R. Boelens).

${ }^{1}$ Address: University of Amsterdam, CEDLA, Roetersstraat 33, 1018 WB Amsterdam, the Netherlands and Wageningen University, Dept. Environmental Sciences, P.O. Box 47, 6700 AA Wageningen, the Netherlands.
} 


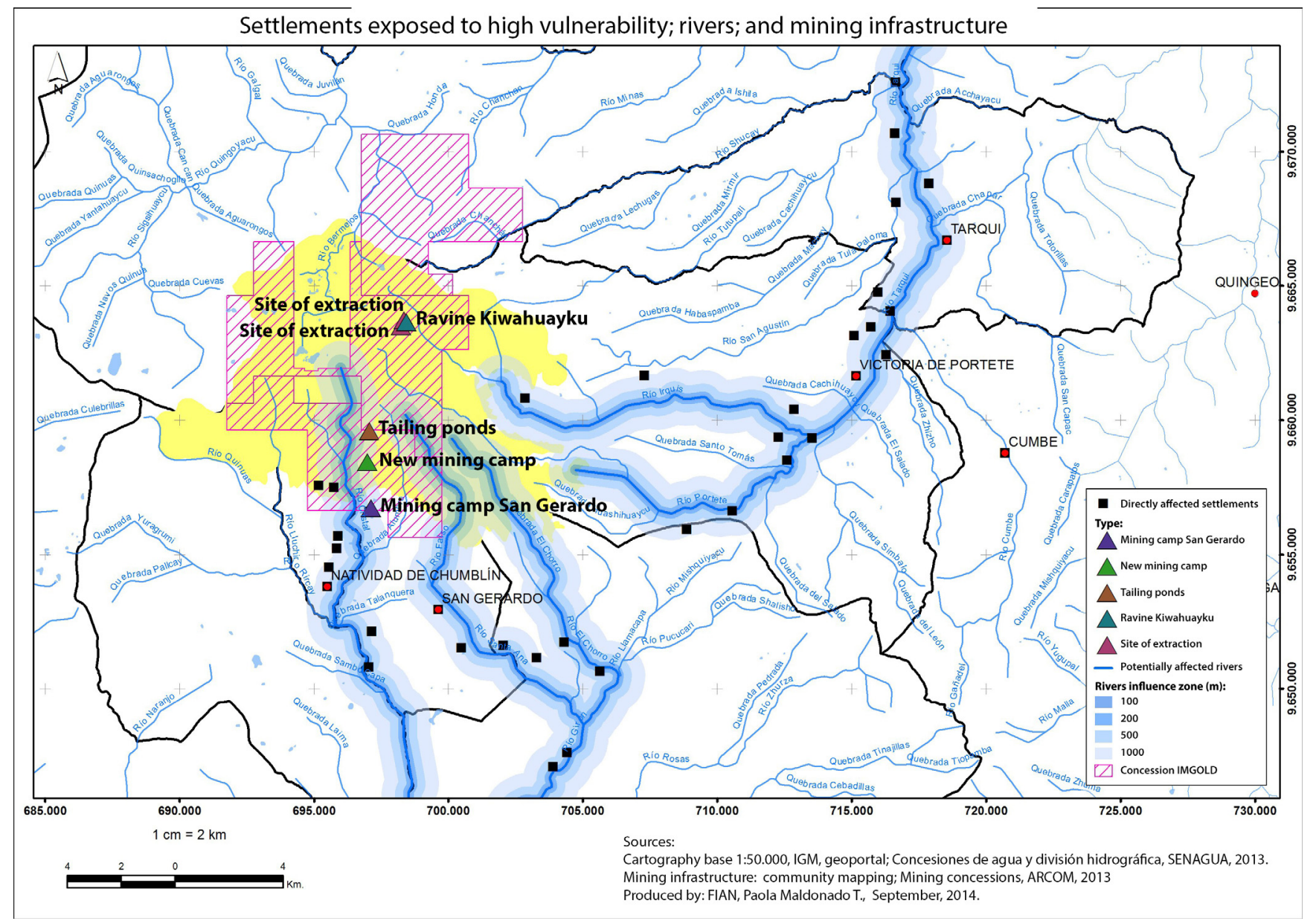

Fig. 1. Map. Translated from Spanish, retrieved from geografiacriticaecuador.org.

mining in the Quimsacocha páramos, the Andean highlands wetlands, softening or silencing resistance. One of the central strategies has been to intend to induce the motto 'Mining for the Good Living' in people's imaginary, which portrays mining as compatible with Nature's Rights and necessary for societal wellbeing (FIDH et al., 2017; Sacher, 2017; van Teijlingen et al., 2016). Where deemed necessary, policy implementation was reinforced with a dose of State force and military repression. The rural communities that opposed the envisaged mining project, counteracted each of the State's strategies by referring to Nature's Rights in their own terms. To examine the way Nature's Rights are used to either support or reject mining, we use the four inter-related 'arts of government' (government-rationalities or 'governmentalities') initially formulated by Foucault $(1991,2008)$ : the regime of Truth, of sovereign power, of disciplinary power, and of neoliberal power (see Boelens, 2014; Boelens et al., 2015; Fletcher, 2010, 2017; Fletcher and Breitling, 2012; Hommes et al., 2016; Wynne-Jones, 2012). Central to Foucault's concept of governmentality is that power is not understood as exclusively negative and coercive, but also as productive and capillary, bottom-up, relational; to become ingrained in the minds, behaviors and every day action of subjects - both the dominant and the dominated. Power and knowledge join together for 'conducting the conduct' by (re)constructing subjects and enabling a desired political order (Foucault, 1980).

Through the analysis of governmentalities in the Quimsacocha mining conflict, we contribute to the newly upcoming discussions about Nature's Rights, the tensions and challenges that result when implementing this ambivalent notion, and the strategies used to set meanings and make tactical use of the recognition of Nature. We pay particular attention to the multi-dimensionality of governmentalities and 'counter-conducts' (Foucault, 2002; cf. Cadman, 2010), and show that there is no unidirectional relationship of government-to-governed, but a two-way flow of interactions and influences, despite the unequal power position of the involved actors. While the Government assigns strategic identities to (and proposes socio-natural relations among) human and non-human residents of Quimsacocha to enable the mining project, we demonstrate how affected communities negotiate and reformulate these subjectivities interactively, defending themselves through material and cultural-political counter-conducts.

The data and information on which this paper is based were gathered during a baseline study conducted in 2012 and through literature reviews as well as the analysis of audiovisual archives, project documentation and mass-media coverage (2014-2015). In addition, field research and interviews with inhabitants of the Quimsacocha páramo and the city of Cuenca were conducted in 2016 and 2017. In the region, community leaders, residents, and water-system leaders were interviewed in Tarqui and Victoria del Portete, the districts most opposed to mining. In Cuenca, Ecuador's third-largest city, we interviewed scholars and stakeholders from the social movement. In Girón region, we interviewed residents of San Gerardo district, where the mining company is based and mining opposition is less; the mining info-center representative and the area's water system leader. Our ample work and research experience in the field of water management and political ecology in Andean highlands' extractive industry as well as with indigenous/rural federations, enabled a comparative perspective and validated findings.

The next section provides an overview over the context of the mining conflict in the Quimsacocha páramo. Section three discusses the four governmentalities and their relevance for exploring mining-related 
tensions emerging in Ecuador. Section four is divided into two parts: first, we deconstruct pro-mining discourses and practices in terms of the four governmentalities, and then analyze the 'counter-conducts' used by grassroots groups and alliances to curb dominant discourses and practices. We examine the State's and the social movement's arguments regarding a lawsuit that was initiated in 2010 to declare the Mining Law un-constitutional. Additionally, we analyze the status of the conflict in Quimsacocha six years after the ruling of the lawsuit was issued (in favor of the mining operation) and at a stage of advanced exploration. Section five expands discussion of Nature's Rights as a 'counter-conduct' strategy. Finally, the last section presents our conclusions.

\section{The context. Mining the Páramos}

Andean páramo ecosystems are typically found in high tropical mountains that are characterized by high humidity and soil water-retention capacity. They are increasingly endangered by environmental degradation because of population pressure, agribusiness, mining, and other, diverse forms of capitalist intervention (see Bebbington \& Bury, 2013; Duarte-Abadía \& Boelens, 2016; Hidalgo et al., 2017; MenaVásconez et al., 2016; Preciado-Jeronimo et al., 2015). The Quimsacocha ('three lagoons' in the Kichwa language) páramo in Azuay Province, Ecuador, is a natural fresh-water reservoir comprising over 30 interconnected lagoons (Pérez Guartambel, 2012) consisting of 11 micro-watersheds that together form the Tarqui, Yanuncay and Rircay watersheds. The first two rivers provide drinking water to the city of Cuenca; the Rircay River reaches Girón region (see Fig. 1).

These territories' water wealth is tapped collectively through irrigation canals and community water systems. Around 2500 families, mainly herders, benefit from irrigation canals that they built collectively decades ago (Pérez Guartambel, 2012; Torres, 2015).

Quimsacocha's gold ore deposits were first explored in the late 1970s but abandoned due to lack of interest in low-grade gold ore. It was only later that the Canadian company IAMGOLD developed concrete plans and obtained concessions in 1998 (Torres, 2015). In 2004, surrounding communities learned of the potential gold project, located $30 \mathrm{~km}$ southwest of Cuenca at $3500 \mathrm{~m}$ altitude, and began to organize. Since then, communities' water organization SCA have sued several times for annulment of mining concessions in water-sourcing zones, the headwaters of the local rivers. To dodge the mining project's association with the páramo's lagoons, the project was renamed Loma Larga in 2012 and the company that would operate the 8030-hectare mining concession became INV Metals Inc., a subsidiary of IAMGOLD (Cuenca, 2013; Sacher and Acosta, 2012). The project, currently in the advanced exploration phase, plans an underground mine to extract 1.86 million ounces of ore over 13 years (INV website; Kuipers, 2016).

Both the company's own studies (INV, 2016) and independent technical reports warn of the mine's risk of acid drainage. Not only may surface water dry up, but given that the rock contains arsenic, mining is very likely to trigger chronic acid drainage, leaching heavy metals, polluting surface and underground water resources for centuries (Kuipers, 2016). Quimsacocha communities' anti-mining battle has defended their water from the outset, alarmed about potential water scarcity and imminent pollution affecting agriculture and livestock livelihoods. Concerns about the possible impacts of mining activity in the páramo involve survival concerns, but are also about the aesthetic, cultural and spiritual value of Quimsacocha's sacred waters (Pérez Guartambel, 2012: 83).

Breach of the Mining Mandate (2008), approval of the Mining Law (2009), and the draft Water Law (2010) triggered mobilization by rural/indigenous and societal organizations nationwide to reject mining extraction in water-source zones. Also in Quimsacocha, rallies, peaceful marches, mobilizations and highway blockades have increased in scale and intensity since 2008, with hunger strikes, injuries and arrests as Ecuador's Government pushed large-scale mining forward. Their resistance has been expressed in numerous actions with local, national and even regional impact. In 2006, 2009 and 2010, SCA closed several highways, paralyzing Azuay Province, to reject mining, and imminent approval of the Mining Law and Water Law, respectively. In 2010, SCAs and CONAIE, ${ }^{2}$ the indigenous movement's main organization, sued for that Law's un-constitutionality and participated in the national mobilization against the draft of the new Water Law. In 2011, they organized Ecuador's first community consultation regarding mining; and along with other societal sectors, they held the Continental Gathering of Abya-Yala's Peoples for Water and Pachamama. ${ }^{3}$

IAMGOLD ran up against this well-organized resistance, above all in Tarqui and Victoria del Portete districts and in Girón communities. In addition, the Ecuadorian Government has used not just State force but also social compensation and propaganda with capillary power strategies. This, in addition to authoritarian control over critical organizations: several NGOs and collectives were disbanded (or threatened) through Presidential Decrees created to regulate civil-society organizations' operation. Reasons for closure included "deviating from their original purposes" and "undermining internal or external State security or affecting public peace". The next section builds on Foucault's theories of power and resistance as the frame to understand each actor's multiple strategies in Quimsacocha's mining conflict.

\section{Four interwoven governmentalities}

Foucault's initial conceptualization of 'governmentality' as the art of conducting populations' conduct (see Foucault 1980, 1982, 1991; Rabinow, 1984) has gradually become broader, more generic and hybrid, analytically interweaving four strategies and mentalities of 'government' and shaping multiple reactions to 'government/governmentality' (Dean, 1999; Foucault, 2007, 2008; see also Boelens, 2014, 2015; Fletcher, 2010, 2017; Li, 2007). Governmentality entails different 'arts of government' (government-rationalities) that “(...) overlap, lean on each other, challenge each other, and struggle with each other: art of government according to Truth, art of government according to the sovereign state's rationality, art of government according to economic agents' rationality, and more generally according to the rationality of the governed themselves" (Foucault 2008:313).

This article uses this multi-dimensional notion of governmentality to better understand the (2007-2017) Rafael Correa Government's multiple strategies to inaugurate large-scale mining in Ecuador, as well as to understand Quimsacocha's communities attempts to counteract these strategies. Proclaiming Latin-American '21st-century Socialism', the Government assembled the necessary institutions and public awareness to maintain a discourse of equitable, sustainable social transformation while favoring penetration by extraction-industry capital, ignoring the rights of affected people. While blandishing its 'world's greenest constitution' that grants Rights to Nature (BBC, 2008; Ministry of Mining and INV, 2016) it persecuted indigenous leaders who opposed the Government's extraction policies (AI, 2012; Calapaqui, 2016) wielding a range of multiform government tactics based on legal force/violence, normalization, moralization, truth claims, and the effort to productively and economically direct society. The different (but interacting) rationalities are all based on 'sovereignty', 'discipline', 'Truth', and 'neoliberalism'.

First, the 'art of government based on Truth' entails politics of acceptance in which indisputable authority derives from unquestionable belief systems. Governments like Ecuador's use unquestionable belief systems, especially Development and natural, positivist Science - for instance in environmental impact assessments showing that

\footnotetext{
${ }^{2}$ Confederation of Ecuador's Indigenous Nationalities (Confederación de Nacionalidades Indígenas del Ecuador).

${ }^{3}$ Abya-Yala ('Continent of Life') refers to the Americas prior to Columbus' arrival; 'Pachamama' to Mother Earth.
} 
environmental harm triggered by mining would be minimal. In particular, a development discourse constitutes a powerful regime of truth with a purely positive value. Power relationships between 'expertise' (neutral, depoliticized) and 'developing' population groups subjected to interventions (Kothari, 2005) are justified by envisaged 'improvements' (Escobar 1995; Li, 2007).

Second, founded on Hobbesian rationality, rule and order in mining territories requires State monopoly over legitimate use of violence: increasingly shared with, or even outsourced to, mining companies' private security forces, to keep populations in line, respecting law and order. In 2008, the necessary institutional-judicial underpinning for mega-mining was issued together with the legal arrangements to oversee/persecute these projects' civil-society critics.

Third, 'neoliberal governmentality' conducts local villagers' behavior and acceptance by approaching them as rational agents who would benefit economically from mining development - individual utilitymaximizers who strategically calculate costs and benefits to materialize their personal interests. In that logic, mining corporations and governments need to install the right economic incentive structures to incorporate local communities in the minescape's order. The 'Citizens' Revolution' government (2007-2017) earned the label of 'post-neoliberal' from new management models for extractive sectors and 'participation through compensation', making (partial) societal redistribution of benefits part of the extractivist economy (Arsel et al., 2016; De Castro et al., 2016:3; Hogenboom, 2012). But, as we will examine, in Ecuador, rather than abandoning neoliberalism the Government transformed and deepened it. And, as elsewhere around the globe, beyond the idealized neoliberal idea of minimizing economic intervention (and maximizing legal intervention), the State intervened both economically and legally, to create propitious conditions for mining - to make the market possible. Beyond laissez-faire, neoliberal governmentality builds on the State's "unceasing vigilance, activity, and intervention" (Foucault, 2008: 132).

Finally, 'disciplinary governmentality' operates through normalizing power (Foucault, 1977), whereby deviant thinking and acting is demoted and delegitimized. Subtly inducing norms for proper, ethical behavior generates 'subjectified subjects' by invoking morality, guilt, mental correction and self-correction. Accepting and reproducing minescapes' discursive and symbolic power-makes communities and villagers 'self-correct' to avoid being considered immoral or deviant. The government and mining companies aim to induce in people a moral conviction that mining means progress, and that anti-mining is morally wrong, as becomes clear in President Correa's statement: "We know there are fundamental, aesthetic and moral principles for respecting nature ... who could favor open-pit mining by itself? But, if that mine happens to present a value of hundreds of thousands of dollars, it would be immoral not to exploit it, losing a great opportunity for the country" (Correa, 2007).

In the empirical realities of minescapes and water governance politics, the four governmentalities tend to strategically entwine and complement each other. The latter two (neoliberal and disciplinary governmentalities) are not based on outright violence or legal force but on a range of often subtle government techniques to productively organize society and induce communities' acceptance, steering conduct bottom-up: "power circulates into the very grain of individuals, touches their bodies and inserts itself into their actions and attitudes, their discourses, learning processes and everyday lives" (Foucault, 1980: 39; Lukes, 2005). In Ecuador, these subtle State strategies for implementing mining projects implied creating subjects' identities, beliefs and behaviors to build up convenient territorial models through controlling natural resources, infrastructure, investments, knowledge and ultimately, populations (Boelens, 2014, 2015; Ferguson and Gupta, 2002; Li, 2007; Rodriguez-de-Francisco and Boelens, 2015; Vos and Boelens, 2014).

Resistance is part of power (Cadman, 2010; Fletcher, 2007). Ecuador's affected communities are not silent victims but engage in multiple forms of resistance to defend their resources and rights, ranging from opposing current distributive inequalities and undemocratic representation, to criticizing the very politics of truth (see Boelens, 2015; Hoogesteger et al., 2016; Hommes and Boelens, 2017; de Vos et al., 2006). “...[I]f governmentalization is this movement through which individuals are subjugated in the reality of a social practice through mechanisms of power that adhere to a truth, ... critique will be the art of voluntary insubordination" (Foucault, 2002:194). ${ }^{4}$ Mining opponents dispute each of the four governmentality strategies with 'counterconducts' in, and versus, these very areas. They grant themselves the 'right to question the truth regime' that engages them as objects and subjects of government (Foucault, 2002). Within political interplay with the governing power, they can question their own identity and subjectivity (Cadman, 2010:550):

(a) In response to the existing 'regime of Truth', in many places, rural communities frequently proclaim the unquestionably sacred nature of their mountains and waters (beyond historically developed and culturally rooted beliefs, norms, rites and cosmovisions). They try new strategic cultural-political currents, (re-)essentialization of indigenous identities and religious/normative systems, or generalized claims of Traditional Ecological Knowledge (TEK). Likewise, they question dominant truths and its strategies increasingly by scientific counterstudies, contesting science's belief system in its own terms. (b) To question the sovereign governmentality, civil society, rural, indigenous and ecologist organizations make strategic (counter-)use of the Law, on a judicial basis, deploying formalistic, legal strategies. (c) Third, they also impugn neoliberal governmentality's monetary value of minerals and their benefits, versus Nature's intrinsic values: "Water is worth more than gold", "Money and gold are no good to drink". Or, on the contrary, they challenge this governmentality by its own techniques: valuing socio-environmental damages and impacts financially, or demanding economic compensations. (d) Finally, if disciplinary governmentality appeals to obedient individuals who are aware of their moral duty to achieve a prescribed modern development for their family and nation, mining opponents equally appeal to people's ethical orientation. A fundamental backbone of their responses to dominant power are the multiple ways in which they manifest the moral obligation to defend Nature. This morality sharply contradicts the morality promoted by the government to underpin mining interests.

The following sections will explore the diverse governmentalities employed in the mining politics in Quimsacocha to steer communities' conduct, as well as the multi-dimensional counter-conduct responses.

\section{Power and counter-power in four layers of governmentality}

Although indigenous organizations did not promote the inclusion of the Rights of Nature in the new Ecuadorian Constitution, they eventually decided to support the official recognition as an 'epistemic pact' and strategic tool (see Valladares and Boelens, 2017). In this section, we examine how the Rights of Nature were strategically used by Quimsacocha communities to contest the four governmentalities that were deployed in the context of the contested mining project.

Ecuador's indigenous movement, represented by CONAIE, has played an important political role, especially since the 1990s when it became the continent's strongest organization (Yashar, 2005). Ethniccultural identity, intimately linked with territoriality and environment,

\footnotetext{
${ }^{4}$ Contrary to deterministic interpretations, Foucault's concept of (disciplinary and neoliberal) power is not that it is "all-powerful", but "infinite" (cf. Gordon, 1991:47). Unlike liberal-humanist approaches, Foucault (1982, 2002) elaborated on subjects' resistance to normalizing powers while they continue to be embedded in 'subjectifying' socio-technical, normalizing environments - as in Ecuador. Where Marx observed that human beings make history, albeit not in conditions of their own choosing, Foucault (1988:84) would argue that "there is no power without potential refusal or revolt" but not in independent, autonomous ways, as conceptualized in liberal notions of presumably 'self-made man'.
} 
is crucial in their political action and relations with indigenous and non-indigenous stakeholders (Lalander and Ospina, 2012). This ethniccultural identity is rooted in both political/cultural history and conscious political strategy-making (Baud et al., 1996; Martínez, 2014), and binds together widely ranging ideologies and politico-cultural perspectives among CONAIE's members. It seeks, among others, to confront ethnic stereotypes that have been historically constructed around "white men's needs" (Berkhofer in Grande, 1999:309). During, and even before, the Conquest, indigenous people were imagined and classified as 'good' or 'noble' whenever this favored white interests, or as 'bad', 'ignoble' or 'non-authentic' whenever they posed an obstacle. Such utilitarian simplifications continue to circulate - paradoxically even more so in times of multi-culturalism (see Hale, 2002). What is more, related stereotypes and 'essentialisms' are often deployed by indigenous organizations themselves in their own 'identity politics' (e.g., Andolina, 2012; Baud et al., 1996; Laurie et al., 2005; Radcliffe, 2012).

When they took office in 2007, the Citizens' Revolution Government used similar utilitarian simplifications to gain support from the indigenous movement. Though not direct allies, indigenous organizations at first supported the Government since it claimed to be anti-neoliberal and supporting peasant-indigenous interests. The new 2008 Constitution included historical indigenous-movement demands, such as the pluri-national State and the new concepts of Good Living and Nature's Rights. The indigenous political support broke down shortly after the elections, when the Government's decision to promote an extraction-based agenda became clear. CONAIE and the Pachakutik Party, its political arm, started openly opposing the Government.

Since then, Rafael Correa's Government campaigned to de-legitimize indigenous leaders and win over grassroots organizations' loyalty, using ethnic identity and cultural rights to divide and weaken the indigenous movement. In Hale's terms, the Government distinguished between 'good ethnicity' ('allowed Indians') that accepts extractivism and related norms and practices, and 'dysfunctional ethnicity' ('backward' or 'radical Indians') who only want to generate conflict (Hale, 2002, 2004). Correa harshly criticized indigenous leaders: "Long live the Citizens' Revolution, which is already a legend; a little pack of troublemakers cannot stop it, even if they wear a poncho" (President Correa, in Agencia Andes, 2015). Regarding Quimsacocha, Correa questioned the 'authenticity' of Carlos Pérez-Guartambel, ${ }^{5}$ leader of the anti-mining resistance, when he was elected President of Ecuarunari, CONAIE's Highlands affiliate. "Another stone-thrower is President of Ecuarunari, without even being indigenous" (idem).

In turn, the indigenous movement also used ethnic stereotypes to garner international support. International environmental defense networks are, consciously or unconsciously, keen to use the image of the “ecologically noble savage" (Grande, 1999: 309; Tanasescu, 2015) from whom 'white society' must learn to prevent the feared ecological collapse (International Rights of Nature Symposium, 2018). Therefore, historically-rooted, locally-grounded ('vernacular') indigenous practices/knowledge are intermingled with the strategic use of stereotypes, to win supporters for their local battles, such as defending the Quimsacocha páramos. Thus, both the Government and the indigenous movement often construct a modernist, dichotomous, essentialist image of 'indigenous' around their own position in the mining conflict: accepting mining for the country's development - according to official discourse - or living in harmony with Pachamama and sacred water. We analyze the different political strategies in detail below.

\footnotetext{
${ }^{5}$ In August 2017, the leader changed his name to Yaku Sacha, which means 'Water from the Forest' in the Kichwa language.
}

\subsection{Framing the promotion of mining as 'revolutionary': four governmentalities}

\subsubsection{Truth governmentality}

The Government's discourse regarding Quimsacocha has been profoundly based on a deep (almost-religious) belief in modernist progress and expert knowledge, claiming indisputable scientific expert authority to promote 'responsible mining'. Technology, studies and laws are used by politicians and technicians to assert that all territorial projects are in the communities' and countrýs best interest. Such 'Truth-based art of government' portrays mining as an unquestionably necessity for modern life, and its costs (minimized by cutting-edge technology) as the costs of progress that need to be tolerated to get Ecuador's people out of poverty. When President Correa unveiled the first gold bar mined during his government, he proclaimed "God might even punish us for failing to tap our mineral resources. How many countries wouldn't love to have Ecuador's wealth?!" (Correa, 2011a).

To further support the Truth claim that mining is little harmful and necessary for progress, the Mining Information Center was created in 2007 in San Gerardo district. The mining company INV's coordinator claimed mining would not pollute the water but, on the contrary, would even improve water quality: "We could supply more neutral water downstream" and "nanotechnology and bio-technology are the panacea for mining - they prevent pollution" (interview 29-07-2016). This appeal to expert scientific Truth is essential since Loma Larga is a lowgrade ore body (the high-grade deposits are already depleted), where waste generation is immense ${ }^{6}$ and the danger of acid mine drainage high (Kuipers, 2016; Sacher \& Acosta, 2012). The INV official acknowledged that the project is delicate, but that acid would not drain because no rubble would be piled on the ground, the sterile wastes would backfill the mine and the rock's $18 \%$ metal content would be processed without cyanide or mercury, using physical-mechanical processes instead. She explained that they would recycle water, that they have drilled as deep as $400 \mathrm{~m}$ and found no underground water; and that "anyway, water is nature's most noble element, and the easiest to clean. Bacteria can degrade cyanide in water".

The company claims that water recirculation and underground extraction guarantees sustainability: "In Loma Larga, first class science and technology play a fundamental role in the new way of mining, making it different for the environment and for human beings" (Girón region news portal, Achiras, 2017). Thus, the mining industry is constructing a discourse of unquestionable feasibility, claiming short-term economic benefits and mitigation as the imperative to sustain modern life. The Ministry's Mining Panorama TV series ends each program with a segment called "Mining in Your Life" - mentioning how farm tools, solar panels, medical procedures, and many other objects we use every day contain metals, leading to the conclusion that: "because we need minerals to live, extracting and handling them properly is our commitment to everyone". The brochure for communities published by the Ministry of Mining and INV (2016) states that rejecting mining is like wanting to "go back to living in caves", and mining's costs enable future progress (Correa, 2011b). This discourse of scientific-modernist development and linear progress through mining has become an institutionalized social practice, to make it appear to transcend all

\footnotetext{
${ }^{6}$ Producing $10 \mathrm{~g}$ of gold (equivalent to one ring) generates an average of 20-60 tons of rocky wastes and uses $7000 \mathrm{~L}$ of water (Sacher \& Acosta, 2012:75).

${ }^{7}$ Nevertheless, an expert report on Loma Larga warns of water quality and quantity risks posed by a gold project in the páramo (Aljazeera 2011- documentary "Water or Gold"): underground mining could have even greater impacts than open-pit mining because "underground mines are often deeper and further-ranging than open-pit mines (...) which could deplete underground water for kilometers around and impact larger aquifers" (Kuipers, 2016:16). "The project is not viable from a technical and economic perspective and poses a considerable environmental risk" (Kuipers, 2016:37).
} 
societies (Berger and Luckmann, 1966; Escobar, 1995).

\subsubsection{Sovereign governmentality}

To strengthen its control and steer villagers' conduct, the Correa Government strategically combined this technical-scientific belief system with legal control and imposition. The Mining Law itself is an act of 'the art of sovereign governmentality', even more evidently when the Government argued in its defense when sued for unconstitutionality. The President of the National Assembly refuted the accusation that the Law violates communities' right to their territory by leaving it open to mining intrusion and appropriation, stating that "the right to own property is also a right recognized in the Constitution, a right not only reserved for indigenous nationalities and peoples" (Constitutional Court, 2010a;11). The President of the Republic said “... the State owns non-renewable resources, so mining activities can satisfy general interests and, if relevant, indigenous communities, peoples and nationalities must place the general interest above their particular interest, according to Good Living" (Constitutional Court, 2010a:18). The State's sovereign authority defines general interest, establishes the Law and holds monopoly over coercive force.

The State's coercive force has been put to use to oppress protests, especially in Tarqui and Victoria del Portete districts. For example in May 2010, when SCA blocked roadways in Azuay province while CONAIE took over the National Assembly in Quito to reject the Water Law's imminent approval, the police repressed protests and arrested several indigenous leaders into custody for sabotage and terrorism. Several days later, the Assembly decided to suspend its vote on that Law.

Such violence, where public force backs the mining company's interests, is no coincidence, but part of constant surveillance and control in the area. Lucía, a Victoria del Portete resident, tells us: "The police were always looking for me (...) The Government has us clearly identified". In public demonstrations, legal responses are backed by police and military violence: "they followed us like dogs there in the fields. Finally, they brought tracking dogs and motorcycles to run us over" (community leader, interview 28-07-2016).

Physical violence and public-private surveillance have become normalized ways of intimidation and control. For example, in the waiting room at the Mining Information Center, every visitor is photographed. During our visit for an interview with the coordinator, we were asked to register with our name, ID number, and organizational affiliation while the receptionist filmed us.

More generally, Correa's Government has intensified and extended sovereign control over society. Decree 16 enables closure and threats to close critical ecological organizations. Surveillance and spying by SENAIN (National Secretariat of Intelligence) over societal sectors includes indigenous and ecological networks. An amendment to the Integrated Criminal Law Code made it possible to prosecute people protesting against mining projects through road blocks for sabotage and terrorism; controversial 2015 constitutional amendments gave the armed forces the 'complementary' role of supporting internal State security - in practice, to militarize territories who resist large-scale mining.

\subsubsection{Neoliberal governmentality}

Both the Government and the mining company in Quimsacocha appeal to market forces as external incentives and mechanisms to control the public, making social investment of royalties in districts near the project. A few steps from the Mining Information Center, a large, modern Health Center is being built for San Gerardo district, while Victoria del Portete already has its 'Millennium School' operating, thanks to mining royalties. Millennium Schools and Communities uniform, standardizing, appealing to the material needs of those affected - are built by the Ecuador Estratégico state company in areas of strategic national projects (see van Teijlingen, 2016; Valladares and Boelens, 2017; Hidalgo et al., 2018). They symbolize the economic materialization of this new natural resource management model and the participation model for communities; and are conditioned on implementing the mining project. During his visit to Quimsacocha in 2011, Correa said: "there are groups who say no to mining, but this harms human life, because where are we going to get the money for hospitals and schools?" (El Ciudadano, 2011).

With this same logic, the Information Center told us about poverty rates in zones surrounding the project and the behavior one could expect from the local inhabitants based on their economic situation. "Opposing a mining project is a headache that residents don't want to have, because they have to feed their children" explained the Center's official (interview 29-07-2016). Her socio-economic analysis portrays large-scale mining as the only viable source of income for a non-viable rural economy full of backward collective, non-market relations "agriculture has already lost here" (idem). Neoliberal rationality of mining presents only 'win-win' economic opportunities.

In the information leaflet distributed by the Ministry of Mining and the mining company in communities, an expert project engineer explains to the fictitious character 'Doña Carmen' that Loma Larga "will create many benefits for communities because taxes will pay for public works". In that same leaflet, another fictitious character called 'Don Manuelito' exclaims "sure, that is why we see new things appear, such as health centers, schools, highways..." and the engineer adds "and not just that: universities and public services, too - it is all invested in the people and their needs" (Ministry of Mining and INV, 2016 leaflet).

Loma Larga's technical data and economic calculations are repeated over and over - the project's cost-benefit ratio overshadows any possible environmental and social impact. They establish a universalistic 'logic of equivalence' among communities' needs, environmental responsibility, and the State's and Company's interests (Li, 2011); they also allow for calculating the (positive) balance between happiness/ benefits versus sacrifice/costs of the extractivist intrusion (Hommes and Boelens, 2018), so legitimizing the mining intervention (cf. DuarteAbadía and Boelens, 2016). As Espeland and Stevens explain, "commensuration produces homogeneity, simultaneously concealing risk and threatening the intensity and integrity of what we value ... rendering some aspects of life invisible or irrelevant ... changing what can be talked about, how we value... Commensuration can be understood as a system for discarding information and organizing what remains into new forms" (1998:314-319). Cases such as Quimsacocha show how commensuration is not just a technical process, but a profoundly political and social thrust.

\subsubsection{Disciplinary governmentality}

Via compensation measures, training and education, the Government tried out new territorial governance tactics and coined new imaginaries and subjectivities to legitimize the National Development Plan, in which extractive activities play a key role. Consciously devised strategies entwined with unconsciously adopted, deep convictions of State officials and followers suggest that moral citizens must support mining out of their internalized civil responsibility for the Nation and progress for all (van Teijlingen, 2016). This molding of subjectivities and identities in Quimsacocha's hydro-territorial minescapes, to configure a desired political and territorial order sustaining the mining project, is expression of what Foucault (1980) describes as a disciplinary art of government.

After the harsh, crude face of open neo-liberalization in the 1990s when the Government abandoned essential social and public tasks, the active presence of State institutions during Correás "21st-century socialism" brought some material benefits to rural towns but also generated deep impacts - because this State presence aimed to concretize a predetermined profoundly normalized (disciplinary) territorial design. In official discourse, Good Living means modern, responsible mining; and Quimsacocha inhabitants are actively invited to be part of it. Materializing the notion of 'managed multiculturalism' (Assies, 2010) or 'neoliberal multiculturalism' (Hales, 2002), disciplining people 
through 'inclusive' policies draws the earlier mentioned dividing line between the 'permitted Indian' and his/her 'a-moral, dysfunctional' counterparts (Hale, 2004). The 'compatible ones' negotiate/collaborate and get rewards, the 'incompatible' rebels are oppressed (Boelens, 2014, 2015).

Facilities such as the modern health center and the Millennium School, built with the advance royalties from the Loma Larga mining project, interweave neoliberal and disciplinary governmentality. Inclusion and participation according to the official rules gets citizens what they want - at least that is what is meant to be in the public's minds and hearts. Like other towns nearby the country's most polemic mining, petroleum and hydro-electric projects, Quimsacocha inhabitants already have their Millennium School, the Government's epitome of the educational revolution.

A Millennium School leader in Portete reveals the desired disciplining effect: "Imagine how wonderful it would be for the Millennium School to offer scholarships for our children, so they can become mining engineers!", and "Gold means the Millennium School. Those of us who want a better future for our children have backed the Government and mining" (parent, interview, 28-07-2016). Thus, it is suggested that mining yields education and progress - an imaginary whose impact multiplies and intensifies when local leaders begin to become the spokespersons of this imaginary within their communities and are endowed with authority over the rest, exemplifying capillary power: "I have been in meetings at other Millennium Schools, so I have seen how important they are, and I have brought the message for my people here, too" (idem).

In Quimsacocha and elsewhere in Ecuador, Millennium Communities and Schools operate as Trojan Horses that, along with other similar standardized gifts, reinforce community division to facilitate extractive projects (see, for example, van Teijlingen, 2016; Valladares and Boelens, 2017; Hidalgo-Bastidas and Boelens, 2019). Wilson and Bayon (2017) investigated several of these compensation infrastructures and showed how they are fantasies of modernity that fulfill important political-discursive functions before and during their construction to make people accept or even embrace extractivist projects in their territories. However, they found that many of them stopped functioning shortly after their inauguration, for example because of lack of qualified staff in Millennium Schools. Confirming this, a parent interviewed in Portete expressed his concerns about problems with the lack of teachers and cuts on funding that affect children's school transport and safety. Independent of the infrastructure's operational functionality, it represents a pre-designed space that does not allow for divergent territorial models and that generates deep divisions in the communitarian fabric.

The question that Rafael Correa asked the people when unveiling the country's first gold ingot unfolds the four governmentalities at once. Echoing official reactions to the extraction of the 1970s' first barrel of petroleum (that equally promised 'development'), he rhetorically asked: "The golden bar is ready, and it costs almost 14 thousand dollars. It is for export, to bring Afro and Shuar people out of poverty - or do they want to keep living in poverty? (...) If we are intelligent, here is the great opportunity that God has given us to get out of extreme poverty" (President Rafael Correa, 2011a). The President's Truth regime portrays Quimsacocha mining as a naturalized social-benefit project, unquestionably trustable: mining means poverty elimination, a gift from God. The question also appeals to people's universal calculating intelligence and economic rationality. At the same time, the words pressure people to avoid any deviant, 'un-intelligent' behavior and fall into the amoral conduct of those who do not accept the extractivist project. Finally, it is the Head of State saying this, so the message reeks of sovereign power: mining policy is strategic for the Nation.

\subsection{Counter-conducts from the territorial defense movement: four counter-} governmentalities

Governmentality projects re-construct territories, redistribute resources and decision-making power, and recreate identities. They operate through objectivation (subjects are problematized as objects of governmental intervention) and subjectivation (shaping the subject's ethical relationship with him/herself as a governed subject) (also see Cadman, 2010:553). The State promotes territorial reconfigurations, subjecting spaces/inhabitants economically and materially, legally and administratively, culturally and politically (Elden, 2007; Valladares \& Boelens, 2017); but not without provoking resistance. In Quimsacocha, communities question modernist policy; subjects problematize how the Government, mining and economic-political elites 'assign' them their subjectivity in line with official truth politics. As we illustrate below, they engage in counter-conducts that question the established order, resisting (or using) the same fields of governmentality (absolute Truth, sovereign, neoliberal, and disciplinary) and experimenting with new identities and subjectivities in Quimsacocha's territories.

Responding to Truth governmentality. Quimsacocha communities' beliefs are based on their waters' sacred nature, which challenges the official truth-regime based on unquestionable technical-scientific beliefs. Product of ancestral worldviews, colonialism and religions, the image of 'sacred waters' displays a religious syncretism that combines Catholic references and the lagoons' supernatural properties. "When Correa came, we told him that people come from other places with canes, blind people, to be cured by our water in Girón" (irrigation canal leader, interview 30-08-2016). Worship of the Catholic virgin, in the Quimsacocha páramo to watch over its water, blends with indigenous symbolism such as the chakana (Andean cross) carved into the virgin's breast. In the context of the mining conflict, rituals and offerings to the lagoons came to involve rural, urban, national and international stakeholders who identify with the resistance. The fight to defend water opened up new possibilities to reestablish a relationship with Quimsacocha's water and the notion of Pachamama (Velásquez, 2017). The sacred nature of Quimsacocha's water, respect for Mother Earth, and ancestral spirituality underpin the ethical force rural communities summon to defend their water.

This syncretism intermingles material notions - defending water for survival, the livelihoods and production of communities who drink water from the páramo and herd livestock - with symbolic, sacred notions. This basic premise confronts expert pronouncements. Yaku Pérez, Quimsacocha anti-mining leader and ECUARUNARI President, explains: "We understand clearly that you can't tether a cow next to the spring, because its trampling and its wastes may dirty the water. Mining activity using chemicals makes our sensitivity and understanding of water shudder ... this opposes our communities' tight, spiritual, profound relationship" (interview, 24-06-2016).

Pérez, an indigenous leader and attorney, coordinated the SCA/ CONAIE's lawsuit for the Mining Law's unconstitutionality. The SCA "defended water not as a commodity, not as a resource, but as the source of life, that enables us to live" (idem). By contesting the "Truthbased governmentalities' of official pro-mining discourse, the SCA's arguments and counter-conducts in this lawsuit combine native, vernacular Andean beliefs and their symbolic and historical meanings, with the force of political-strategic conviction. The SCA denounce that the Mining Law violates Nature's Rights and the human right to water: "The Mining Law allows the destruction of Nature and her womb where life flows like water" (SCA, 2009:5).

Boundaries blur between deeply felt belief systems based on spiritual Truth, and the strategic-political use and convenience of 'sacred, supernatural waters'. This is a widespread, expanding practice in Andean anti-mining movements: reference to Mother Earth, spiritual values and sacred meaning finds strong resonance in the national/international environmentalist movement, and is often strategically deployed, hybridized and functionalized to build multi-scale counter- 
movements (Andolina, 2012; Valladares and Boelens, 2017). This clever instrumental-functionalist tactic does not, however, deny that important key values are rooted in Andean cultures and histories (Cf. Boelens, 2014; Grande, 1999; Lemaire, 1986; Paredes Peñafiel and Li, 2017; Taylor, 1994). For instance, as Cajamarca indigenous woman Rosa, in the documentary 'Daughter of the Lake', cries out - "When they destroy the lakes, where will the owners go? Not the humans, but the spirits of the lakes. They take care of our lakes. Mother Water, blood is spilled for gold....... Mother Water, don't they know that you are a living being?" - this is a powerful message to Peruvian and international society, bonding indigenous and non-indigenous mining-opponents, in the global South and North (in Cabellos, documentary, 2015). Boelens (2014) and Li (2013) show how Apus (Andean mountain deities and territorial water lords) may be strategically deployed and enacted to defend or establish human territorial-political interests. The movements' cultural politics defending nature and territories, contain both vernacular and strategic features of 'sacredness'; counter-conducts combining cultural and political knowledge in new epistemological frameworks to confront dominant power plays geared to appropriate nature both materially and culturally.

Responding to sovereign governmentality. Resistance to mining intrusion also questions the Government's sovereign governmentality, by entering that very legal battlefield. The dissenting vote substantiation by Dr. Nina Pacari (the only indigenous judge on the Constitutional Court) illustrates this. Pacari questions whether the National Assembly's mentions of 'equality under the Law' and the 'concept of a unified State' are being stretched to disregard the country's existing pluri-nationality. She criticizes that the State authority may argue that Good Living "places general interest above particular interests" to justify not having consulted over the Mining Law with indigenous peoples and nationalities. Judge Pacari writes "unity does not mean uniformity. Ecuador hosts culturally different peoples and communities who, as much as majority groups, deserve protection by the State" (Constitutional Court, 2010b:30). Pluri-nationality entails recognition of indigenous authorities and their autonomies, quite unlike the Governments' practices of sovereign governmentality.

Significantly, this battle against sovereign governmentality does recognize law and formal structures as a source of power, and appeals to them to dispute them (cf. De Castro et al., 2016; Sosa et al., 2017; Stoltenborg and Boelens, 2016). The history of Quimsacocha and Ecuador illustrate how the indigenous/environmental movement has sought to influence, use, and change State Law and structures. For example, in 2011, community water-system users in Tarqui and Victoria del Portete districts held Ecuador's first community consultation about mining in their territories. Although not officially recognized, the consultation clearly showed that $93 \%$ of the people did not agree with mining activities. In 2015, Girón region collected enough signatures to call for an official referendum about mining. The National Electoral Council (CNE) approved the signatures and forwarded the matter to the Constitutional Court to rule on its constitutionality. One year later, the Court had not yet ruled on the question, and 2015 amendments to the Constitution prevented citizens' calling consultations on issues of interest. But as of November 2018, the transition CNE permitted the referendum about mining in Quimsacocha. CNE President's argumentation is remarkable: "For the Rights of Nature...for local identity, for those páramos part of the sacred world, of Pachamama. (...) For ethic, aesthetic, and poetic reasons of coherence with the future, I vote in favor" (Resolution CNE transitory-19-11-2018). Discourses about identity, inviolable sacredness of territory and Nature, posited by social and ecologist organizations as overarching Truth or all-encompassing moral, sometimes permeate the system and mechanisms of sovereign power.

In the arena of sovereign power, resistance to mining in the legal field is often combined with counter-conduct strategies expressed by protests, peaceful resistance actions and road blocks - which officialdom often meets with physical-military violence and by sending leaders to jail on charges of 'environmental terrorism'.

Responding to neoliberal governmentality. Questioning sovereign power is combined with questioning neoliberal power. Judge Pacari continues: "An exercise of weighing rights must establish what should prevail: general interest in economic terms, or interest in defending a collective right, positive discrimination and direct application of intercultural and pluri-national principles ... This is the case of indigenous peoples and nationalities, whom understand 'Sumak Kawsay' ('Good Living') from a particular worldview: rootedness in their territory and their natural resources is the base for their knowledge, spirituality or culture and their very existence" (Constitutional Court, 2010b:33).

The indigenous movement feels their territory cannot be economically valued or compensated for, because it involves their identity. CONAIE tenaciously opposes the economic rationality that the State uses to promote mining in indigenous territories and impugns the Mining Law because its "norms have been fabricated under the Western postulate of commodity trade, a reasoning that is not shared by indigenous communities, whose territory is not replaceable, much less susceptible to economic valuation" (Constitutional Court, 2010a: 6). Judge Pacari feels that mine's land titles and roads (right-of-way) in indigenous territories could affect "the indivisibility of the territory" because such territorial division "pertains to a conventional, limited notion of land, as an element of trade and production, which differs from indigenous peoples' notion" (Constitutional Court, 2010b:34).

Economic commensuration, devising a common economic metric for (potentially) mining-affected territories, properties and livelihoods is strongly contested because, as Espeland and Stevens observe, it “... transgresses deeply significant moral and cultural boundaries" and "can repudiate identities that are closely linked to incommensurable values" (1998:326). At the same time, territorial defense is complex and ambivalent; and defining what and when something is incommensurable is not always 'intrinsic' but can also be strategic; for example, when affected people use the very nature of territories' incommensurability to negotiate for higher compensations. This has not happened in Quimsacocha, where compensations are imposed by the State, and the project's early stage has not yet affected people.

A local irrigation leader feels that economic assessment of the páramo in terms of underground gold is unfathomable. "It is beautiful to see the Quimsacocha páramo soak up water like a sponge. Our country is truly rich, but the Government can't see this" (interview, 3008-2016). Inhabitants opposing mining in Girón, the district that has received the most compensatory social works, say: “... what is a golden floor worth, without water. We can't drink gold .... What use is the health subcenter they have built in our community, if mining will make us sicker?" (resident of Girón, interview 29-06-2016).

Responding to disciplinary governmentality. The anti-mining struggle also engages in counter-conducts against disciplinary governmentality by appealing to morality: the struggle for water is equated with the fight for life and the ethical imperative to take care of Pachamama. The very name of the so-far largest mobilization against mining that covered ten provinces of Ecuador during almost two weeks in March 2012, is a clarion call: the 'March for Water, Life and Peoples' Dignity'.

Mining opponents insist that water cannot be traded for gold because of its socio-economic, cultural or moral value. Upholding the Quimsacocha páramo's incommensurability, inhabitants "deny that the value of two things, water and gold, is comparable" (Raz in Espeland and Stevens, 1998:326). Establishing páramos incommensurability reinforces the notion that it is the moral duty of every inhabitant in Quimsacocha to defend life, and the sacredness of páramo and water, promoting a passive power that people identify with and adjust to. For example, indigenous leader Yaku Pérez discusses the morality of another socio-environmental battle, defending the Yasuní ecological reserve: "Someone who cannot tune in with Nature, water and life cannot grasp the value of Yasuní" (Castillo, 2014). In such counter-disciplinary discourses, cultural-historical, vernacular worldviews dynamically intermingle with movements' consciously devised political strategies: 
"Defining something as incommensurable can serve as a political strategy" (Li, 2011:70), as it creates non-tradable, non-negotiable categories with boundaries that must not be transgressed.

On the one hand, this normalizing, moralistic counter-conduct challenging disciplinary governmentality may express consciously designed alternative institutional strategies and political structures. For example, 'Ethical Tribunals' are promoted by international environmental movements such as the Permanent Tribunal of the Peoples (1979) and the Tribunal for Nature's Rights (2014). The regional 'Continental Gathering of Abya-Yala's Peoples for Water and Pachamama', organized, among others, by SCA in Cuenca in June 2011, ratifies "the International Ethical Tribunal's legitimacy and the moral validity and authentic expression of justice by the world's peoples (...)" (OLCA, 2011).

On the other hand, probably more influentially, counter-norms are produced and manifested as acts of 'non-conformism', often unconsciously on an ordinary day-to-day basis among those groups that challenge State rules and (mining-enterprise) market morals (also see Boelens, 2015). One resident told us: "At a presentation, a provincial authority raised a bottle of water to his mouth; I took it away and told him 'what are you drinking water for, if you are supporting the miners go drink gold'. When the police were beating us with their clubs, I shouted 'I'm defending you, so you can drink water, too'" (irrigation canal leader, interview, 08-2012). This way, on different scales and both institutionalized and informally, normalizing power is opposed by forces of non-conformity and counter-moralism that appeal to the (concrete and presumed) existence of common well-being, community reciprocity and the moral economy.

Recently, after the phase of intensified mining exploration, Quimsacocha mining activity has stopped. According to residents and SCA, this is because of their resistance. "Mining has stopped because of the people's movement" (community leader, interview, 28-08-2016). Mobilizations have also appealed to urban inhabitants through highlighting the impacts that mining would have for Cuenca city. The Mayor and Council of Cuenca have declared their authority over land use and that Cuenca and its páramos will be free of mining activities (El Mercurio, 2017). The referendum called by the country's new President, Lenín Moreno for early 2018, included a question about prohibiting metallic mining in determined zones. ${ }^{8}$ Beyond its effectiveness, the inclusion of a question about 'mining' acknowledges the issue's transcendence and the conflicts it has generated in Ecuador.

\section{Rights of nature as a battlefield between governmentalities and counter-conduct}

Conflicts over water and extractive industries in Ecuador confront Nature's Rights (recognized constitutionally in 2008) with the intensifying extractive model that takes place in the so-called strategic sectors (Senplades, 2009, 2013). Civil society proposed Nature to be included as a rights-holder in the new Constitution to limit the State's sovereign power and the market's power over territorial interventions, and as an epistemological strategy. Disputes over the meaning, contents and application of these rights reflect the battle between the 'conductof-conduct' and 'counter-conduct' around the different meanings of 'Nature' promoted in favor and against mining. These various notions of nature reinforce indigenous demands for a pluri-national State and other, non-neoliberal ways to value and manage territories. However, Nature's Rights also entail, above all, legal strategies that, paradoxically, have proven useful as a legal tool for the Government to promote 'Mining for Good Living'. (see also Valladares and Boelens, 2017; Rawson and Mansfield, 2018). Let us examine, once again, the

\footnotetext{
8 "Do you agree with amending the Constitution of the Republic of Ecuador to prohibit metallic mining in all stages, in protected areas, in no-take zones, and urban centers...?"
}

four modalities of governmentality, now to focus explicitly on how Nature's Rights are deployed.

The State proposes, as an immovable regime of Truth, that human beings are the most important part of nature and must be supplied with natural resources to subsist. Under this human-nature relationship, Nature's Rights are presented as additional guarantees to minimize environmental impacts. These rights are promoted by sovereign power: State political will and institutions will ensure that mining operations are environmentally responsible. Nature's Rights are also useful for neoliberal governmentality, proliferating instrumental rights and participation to generate economic incentives. In this way participation and controls are supposed to guarantee that economic benefits outweigh mining impacts, creating a positive, utilitarian costs-benefits calculation to the benefit of all. Moreover, as the argument goes, it is necessary to use and exploit nature in order to save and improve her. Finally, disciplinary power has established the boundaries of Nature's Rights and defined up to what point and under what circumstances citizens can demand them. None of the lawsuits brought on behalf of these rights to stop large-scale strategic projects has had any effect, whereas the judgments in favor have been, above all, in suits by the State against illegal activities by individuals or small enterprises affecting nature. This demonstrates the complicated character of Nature's Rights (see also Valladares \& Boelens, 2017; Rawson and Mansfield, 2018): They are morally laden rights that appeal to a vague or multi-interpretable meaning of nature. Also, in theory, 'any' person has the right to represent Nature (Tanasescu, 2013), whereas in practice it is often the most powerful who does so. In Ecuador, it is especially the State that can (and actually does) speak on behalf of Nature according to the most convenient definition of Nature, positing its moral grounds and Truth.

Quimsacocha's inhabitants appeal to Nature's Rights against mining the páramo, both legally and in their daily practices. Deploying the truth regime against State, company and elite power, they insist that human beings do not outrank Nature, but are part of it and constantly interact with Pachamama. Within their sovereign counter-conduct, communities demand that the State fulfill its obligation to legally recognize these notions and relations of Nature and identity. They denounce that giving in to mega-mining means violating Nature's constitutional rights to exist, be maintained and regenerate. ${ }^{9}$ Lawyers involved in the legal application of Nature's Rights assert that these rights work as collective rights to Nature, which means that intrusion can be opposed at the sake of the ecosystems themselves, independently of whether there are human settlements around (potentially) affected areas. Counter-conduct against neoliberal governmentality is complemented by disciplinary governmentality used by communities in their resistance, questioning the short-term, economist's approach to exploiting nature, and overlaying the ethical duty to care for life and for coming generations' future.

Quimsacocha's inhabitants and those backing their anti-mining resistance use these counter-conducts strategically (legally and extralegally) and also in connection with broader political and epistemic communities (Bebbington, 2013). Local to international groups with varied identities (communities, academics, politicians, practitioners, etc.) discuss the implications and potential of recognizing Nature's Rights to frame public debate with new ideas and discourses, to yield other viable models, coalitions and mobilizations.

\footnotetext{
${ }^{9}$ Article 71 - Nature or Pacha Mama, where life is reproduced and realized, is entitled to respect for its existence, and for the maintenance and regeneration of its life cycles, structure, functions and evolutionary processes. Any person, community, people or nationality may demand that the public authorities enforce and respect the Rights of Nature. [...] The State will encourage individuals and corporate bodies and collectives to protect nature, and will promote respect for all elements comprising an ecosystem.
} 


\section{Conclusions}

To make 'mining' equal 'Good Living' - and make extractivism compatible with 'Nature's Rights' in the public eye, the State and its institutions employed a broad range of power strategies. Analyzing the mining conflict in the Quimsacocha páramos, Azuay Province, through Foucault's four governmentalities shows how repressive mining-policy strategies have mingled with other, subtler, capillary power. This capillary, productive power has attempted to assign identities to human and non-human subjects in Quimsacocha and to their inter-relations, and set boundaries on rural/indigenous political participation.

The promoted socio-economic redistribution discourse obliges indigenous communities to accept mining in their territories in exchange for compensations and basic facilities, fitting clearly into neoliberal 'poverty-reduction' policies without addressing economic inequality, which would entail measures for social justice and effective participation. Communities affected by extractivism can claim their rights as long as they do not affect the dominant production regime.

However, where there is power, there is resistance. Quimsacocha inhabitants defend their territories from mining by disputing each of the four 'arts of government' attempting to govern them. These counterconducts occur in formal political and legal settings, but above all in communities' day-to-day practices. Affected communities problematize the subjectivities imposed by the Government, mining and elites as the regime of truth, and reformulate new subjectivities and identities by practicing identity politics.

Using Nature's Rights to promote mega-mining reflects the constraints on recognizing and exercising rights under neoliberal governance, and shows how the State expands its capacity to neutralize and distort political opposition by its utilitarian application of such rights to back neoliberal economic measures. Interestingly, the way the State is able to use Nature's Right to promote large-scale mining depicts the tensions inherent to their constitutional recognition. In the impossibility of defining Nature, and the challenge of recognizing legal (that is, human-invented) 'rights' to a largely non-human and 'voiceless' entity, both the State and citizens communities are able to claim a 'convenient definition' and to encompass recognition and voice to their moral stand points and needs. Originally conceived as a tool to limit State power and expand indigenous territorial rights, in practice the unspecified guardianships to speak for Nature ${ }^{10}$ allows powerful actors (such as the State, or other entities able to accumulate strong legal voice) to reframe these rights and the scope of their implementation.

However, although the State aimed to stifle debate about the development model, economic system, and pluri-nationality implicit in such rights, communities erect their own truth regime as a counterconduct, framing a different socio-natural order. They build alliances and coalitions at various geographical scales, creating epistemic civilsociety coalitions for territorial and environmental defense. Where ethnic identity, historical-vernacular roots and strategical-political objectives come together, powerful resistance movements evolve to challenge extractivism, legalistic Nature/identity maneuvers and neoliberal recognition politics.

\section{Words of thank}

We thank Samuel Dubois and Lena Hommes, as well as three anonymous reviewers, for their invaluable support to improving this manuscript.

\footnotetext{
${ }^{10}$ Compare the case of New Zealand, Australia and Canada (Sanders, 2018; Jackson, 2018; Jackson \& Barber, 2013; Wilson \& Inkster, 2018; Yates, Harris \& Wilson, 2017).
}

\section{References}

Achiras, 2017. Loma Larga es Ciencia y Minería, 12 October 2017. Girón online portal. Available at $<$ http://achiras.net.ec/proyecto-loma-larga-ciencia-mineria $>$.

Agencia Andes. Discurso del presidente Rafael Correa ante marcha indígenas. Published 13 August 2015. Available at < https://www.youtube.com/watch?v= T5qj31 kx8Hw >

Andolina, R., 2012. The values of water: development cultures and indigenous cultures in highlands Ecuador. Latin Am. Res. Rev. 47 (2), 3-26.

Amnesty International, 2012. Para que nadie reclame nada ¿Criminalización del derecho a la protesta en Ecuador? Editorial Amnistía Internacional, Madrid.

Arsel, M., Hogenboom, B., Pellegrini, L., 2016. The extractive imperative and the boom in environmental conflicts at the end of the progressive cycle in Latin America. Extractive Ind. Soc. 3, 877-879.

Assies, W., 2010. The limits of state reform and multiculturalism in Latin America: contemporary illustrations. In: Boelens, R., Getches, D., Guevara-Gil, A. (Eds.), Out of the Mainstream. Water Rights, Politics and Identity. Earthscan, London and Washington D.C, pp. $57-73$.

Baud, M., Koonings, K., Oostindie, G., Ouweneel, A., Silva, P., 1996. Etnicidad como estrategia en América Latina y el Caribe. Abya Yala, Quito.

Bebbington, A., Humphreys-Bebbington, D., Bury, J., 2010. Federating and defending: water, territory and extraction in the andes. In: Boelens, R., Getches, D., Guevara-Gil, A. (Eds.), Out of the Mainstream. Water Rights, Politics and Identity. Earthscan, London and Washington DC, pp. 307-327.

Bebbington, A., 2013. Natural resource extraction and the possibilities of inclusive development: politics across space and time. Graduate School of Geography, Clark University and School of Environment and Development, University of Manchester. ESID, Working Paper, 21.

Bebbington, A., Bury, J. (Eds.), 2013. Subterranean struggles: New dynamics of mining, oil, and gas in Latin America. University of Texas Press, Austin.

BBC, 2008. Ecuador tiene la Constitución más verde. BBC, 2 October 2008.

Berger, P., Luckmann, T., 1966. The Social Construction of Reality. A treatise in sociology of knowledge. Penguin Books, London.

Boelens, R., 2014. Cultural politics and the hydrosocial cycle: Water, power and identity in the Andean highlands. Geoforum 57, 234-247. https://doi.org/10.1016/j. geoforum.2013.02.008.

Boelens, R., 2015. Water, Power and Identity. The Cultural Politics of Water in the Andes. Routledge/Earthscan, London and Washington DC.

Boelens, R., Hoogesteger, J., Baud, M., 2015. Water reform governmentality in Ecuador: Neoliberalism, centralization, and the restraining of polycentric authority and community rule-making. Geoforum 64, 281-291. https://doi.org/10.1016/j.geoforum. 2013.07.005.

Calapaqui, C. 2016. Criminalización de la Protesta. Memoria de la Resistencia. Ecuarunari, FPN, FUT, Quito.

Cabellos, E., 2015. Hija de la Laguna/ Daughter of the lake, Documentary. Ernesto Cabellos Damian, Producción Guarango.

Cadman, L., 2010. How (not) to be governed: Foucault, critique, and the political. Environ. Plann. 28 (3), 539-556.

Castillo, L., Es un defensor de la gestión del agua en comunidad. Entrevista a Carlos [Yaku] Pérez. El Comercio, Published 23 March 2014.

Correa, R., 2007. Discurso Presidente de la República, Rafael Correa, en la ceremonia de inauguración de la Asamblea Nacional Constituyente, Montecristi 30/11/07.

Correa, R., 2011a. Enlace ciudadano $N^{\circ} 245$ desde Píllaro, 12 November $2011<$ https:// www.youtube.com/watch? $\mathrm{v}=$ ttbz6EyFQ7M > .

Correa, R., 2011b. Enlace ciudadano N ${ }^{\circ} 249$ desde Macas, 11 December 2011. < https:// www.youtube.com/watch? $=\mathrm{qFq} 895 \mathrm{v} 2 \mathrm{Y} 4 \mathrm{Y}>$

Constitutional Court, 2010a. Sentencia N ${ }^{\circ} 001-10$-SIN-CC, 18 March 2010

Constitutional Court, 2010b. Acción Pública de Inconstitucionalidad. Voto Salvado de la Dra. Nina Pacari Vega. Case 0008-09-IN; 0011-09 IN.

Dean, M., 1999. Governmentality. Power and Rule in Modern Society. Sage, London.

Duarte-Abadía, B., Boelens, R., 2016. Disputes over territorial boundaries and diverging valuation languages: The Santurban hydrosocial highlands territory in Colombia. Water Int. 41 (1), 15-36. https://doi.org/10.1080/02508060.2016.1117271.

El Ciudadano, 2011. Declaraciones del Presidente Correa en Quimsacocha. El Ciudadano, 26 October $2011<$ https://www.youtube.com/watch?v=9nzdFwZ3BI8 >

El Mercurio, 2017. Cuenca y El Cajas áreas libre de explotación minera metálica, El Mercurio, 23 January 2017.

Elden, S., 2007. Rethinking governmentality. Polit. Geogr. 26, 29-33.

Escobar, A., 1995. Encountering Development. The Making and Unmaking of the Third World. Princeton University Press, Princeton.

Escobar, A., 2010. Latin America at a Crossroads. Alternative modernizations, post-liberalism, or post-development? Cult. Stud. 24, 1-65.

Espeland, W., Stevens, M., 1998. Commensuration as a social process. Ann. Rev. Sociol. $24,313-343$.

Castro, F. de, Hogenboom, B., Baud, M. (Eds.), 2016. Environmental Governance in Latin America. Palgrave Macmillan. DOI: 10.1007/978-1-137-50572-9.

Ferguson, J., Gupta, A., 2002. Spatializing states: toward an ethnography of neoliberal governmentality. Am. Ethnol. 29, 981-1002.

FIDH, CEDHU, Acción Ecológica, INREDH, 2017. Vulneración de Derechos Humanos y de la Naturaleza en la Cordillera del Cóndor-Ecuador, Quito.

Fletcher, R., 2007. Introduction: Beyond Resistance?: The Future of Freedom. Nova Science Publishers Inc. ISBN 1-60021-032-5.

Fletcher, R., 2010. Neoliberal environmentality: towards a post structuralist political ecology of the conservation debate. Conserv. Soc. 8 (3), 271-1181.

Fletcher, R., Breitling, J., 2012. Market mechanism or subsidy in disguise? Governing 
payment for environmental services in Costa Rica. Geoforum 43 (3), 402-411.

Fletcher, R., 2017. Environmentality unbound: Multiple governmentalities in environmental politics. Geoforum 85, 311-331.

Foucault, M., 1977. Discipline and Punish. The Birth of the Prison. Vintage Books, New York.

Foucault, M., 1980. Power/Knowledge: Selected Interviews and Other Writings, 1972-1977. In: Gordon, C. (Ed.), Pantheon Books, New York.

Foucault, M., 1982. The Subject and Power. In: Dreyfus, H., Rabinow, P. (Eds.), Michel Foucault: Beyond Structuralism and Hermeneutics. University of Chicago Press, Chicago.

Foucault, M., 1988. Politics, Philosophy, Culture: Interviews and Other Writing. In: Kritzman, L.D., Routledge, New York and London.

Foucault, M., 1991. Governmentality. In: Burchell, G., Gordon, C., Miller, P. (Eds.), The Foucault Effect: Studies in Governmentality. University of Chicago Press, Chicago, pp. 87-104 [1978].

Foucault, M., 1978. What is critique. In: Ingram, D. (Ed.), The Political. Blackwell Publishers, Malden, Oxford, pp. 191-211 (1978).

Foucault, M., 2007. Security, Territory, Population. Picador, New York.

Foucault, M., 2008. The Birth of Biopolitics. Palgrave MacMillan, New York.

Gordon, C., 1991. Government rationality. In: Burchell, G., Gordon, C., Miller, P. (Eds.), The Foucault Effect: Studies in Governmentality. University of Chicago Press, Chicago, pp. 1-51.

Gudynas, E., 2010. Si eres tan progresista por qué destruyes la Naturaleza? Neoextractivismo, izquierda y alternativas. Ecuador Debate 79, 61-81.

Grande, S.M.A., 1999. Beyond the ecologically noble savage: Deconstructing the White man's Indian. Environ. Ethics 21 (3), 307-320.

Hale, C., 2002. Does multiculturalism menace? Governance, cultural rights and the politics of identity in Guatemala. J. Latin Am. Stud. 34 (3), 485-524.

Hale, C., 2004. Rethinking Indigenous Politics in the Era of the 'Indio Permitido'. NACLA Report Am. 38 (2), 16-21.

Hidalgo, J.P., Boelens, R., Vos, J., 2017. De-colonizing water. Dispossession, water insecurity, and Indigenous claims for resources, authority, and territory. Water History 9, 67-85. https://doi.org/10.1007/s12685-016-0186-6.

Hidalgo-Bastidas, J.P., Boelens, R., 2019. The Political Construction and Fixing of Water Overabundance. Rural-urban Flood Risk Politics in Coastal Ecuador. Water International.

Hidalgo, J.P., Boelens, R., Isch, E., 2018. The Daule-Peripa Multipurpose Hydraulic Scheme: technocratic reconfiguration of a hydro-social territory and dispossession in coastal Ecuador. Latin Am. Res. Rev. 53 (3), 517-534. https://doi.org/10.25222/larr. 362.

Hommes, L., Boelens, R., 2017. Urbanizing rural waters: Rural-urban water transfers and the reconfiguration of hydrosocial territories in Lima. Polit. Geogr. 57, 71-80. https://doi.org/10.1016/j.polgeo.2016.12.002.

Hommes, L., Boelens, R., 2018. From natural flow to 'working river': Hydropower development, modernity and socio-territorial transformations in Lima's Rímac Watershed. J. Historical Geogr. 62, 85-95. https://doi.org/10.1016/j.jhg.2018.04. 001.

Hommes, L., Boelens, R., Maat, H., 2016. Contested hydrosocial territories and disputed water governance: Struggles and competing claims over the Ilisu Dam development in southeastern Turkey. Geoforum 71, 9-20. https://doi.org/10.1016/j.geoforum.2016. 02.015 .

Hogenboom, B., 2012. Depoliticized and Repoliticized minerals in Latin America. J. Dev. Societ. 28 (2), 133-158.

Hoogesteger, J., Boelens, R., Baud, M., 2016. Territorial pluralism: water users' multiscalar struggles against state ordering in Ecuador's highlands. Water Int. 41 (1), 91-106. https://doi.org/10.1080/02508060.2016.1130910.

International Rights of Nature., 2018, September. Symposium Declaration. Symposium conducted at Universidad Andina Simón Bolivar. Quito-Ecuador. < https:// rightsofnaturesymposium.com/symposiumdeclaration/ >

INV Metals Inc., website < https://www.invmetals.com/projects/loma-larga/ >

INV Metals Inc., 2016. Technical report on the Loma Larga project, Azuay province, Ecuador, August 29th, 2016. < https://www.invmetals.com/wpcontent/uploads/ 2016/08/LL_N143_101_TR_Aug29_2016.pdf > .

Jackson, S., 2018. Water and Indigenous rights: Mechanisms and pathways of recognition, representation, and redistribution. WIREs Water 2018, 5, online. doi: 10.1002/ wat2.1314.

Jackson, S., Barber, M., 2013. Recognition of indigenous water values in Australia's Northern Territory: Current progress and ongoing challenges for social justice in water planning. Plann. Theory Pract. 14 (4), 435-454.

Kothari, U., 2005. Authority and expertise: the professionalisation of international development and the ordering of dissent. Antipode 37 (3), 425-446. https://doi.org/10. 1111/j.0066-4812.2005.00505.x.

Kuipers, J., 2016. Informe Pericial sobre los proyectos Loma Larga y Río Blanco. Provincia de Azuay. Editores del Austro, Cuenca, Ecuador.

Lalander, R., Ospina, P., 2012. Movimiento Indígena y Revolución Ciudadana en Ecuador. Cuestiones Políticas 28 (48), 13-50.

Laurie, N., Andolina, R., Radcliffe, S., 2005. Ethnodevelopment: social movements, creating experts and professionalising indigenous knowledge in Ecuador. Antipode 37 (3), 470-496.

Lemaire, T., 1986. De Indiaan in ons bewustzijn: De ontmoeting van de Oude met de Nieuwe Wereld. Ambo, Baarn.

Li, F., 2013. Relating different worlds: Mines, aquifers and sacred mountains in Peru. Anthropologica 55 (2), 399-411.

Li, T.M., 2007. The Will to Improve. Governmentality, Development, and the Practice of Politics. Duke University Press, Durham, London.

Li, T.M., 2011. Rendering society technical: government through community and the ethnographic turn at the World Bank in Indonesia. In: Mosse, D. (Ed.), Adventures in Aidland. Berghahn, Oxford.

Lu, F., Valdivia, G., Silva, N.L., 2017. Oil, Revolution, and Indigenous Citizenship in Ecuadorian Amazonia. Palgrave Macmillan, Basingstoke.

Lukes, S., 2005. Power and the battle for hearts and minds. Millenium 33 (3), 477-493.

Martínez, E., 2014. La naturaleza entre la cultura, la biología y el derecho. Instituto de Estudios Ecologistas del Tercer Mundo, Quito.

Mena-Vásconez, P., Boelens, R., Vos, J., 2016. Food or flowers? Contested transformations of community food security and water use priorities under new legal and market regimes in Ecuador's highlands. Rural Stud. 44, 227-238. https://doi.org/10.1016/j. jrurstud.2016.02.011.

Ministry of Mining, INV Minerales Ecuador S.A, 2016. Minería justa para el desarrollo. Leaflet distributed for the Loma Larga project.

OLCA (Observatorio Latinoamericano de Conflictos Ambientales), 2011. Declaración del Encuentro Continental de los Pueblos de la Abya Yala por el Agua y la Pachamama. Retrieved 3 February 2018. Available at < http://www.olca.cl/oca/ecuador/ mineras068.htm >

Paredes Peñafiel, A.P., Li, F., 2017. Nourishing Relations: Controversy over the Conga Mining Project in Northern Peru. Ethnos. https://doi.org/10.1080/00141844.2017. 1410490.

Pérez Guartambel, C., 2012. Agua u Oro. Kimsacocha, la Resistencia por el Agua. Universidad Estatal de Cuenca, Cuenca.

Perreault, T., Valdivia, G., 2010. Hydrocarbons, popular protest and national imaginaries: Ecuador and Bolivia in comparative context. Geoforum 41 (5), 689-699.

Preciado-Jeronimo, R., Rap, E., Vos, J., 2015. The politics of Land Use Planning: Gold mining in Cajamarca, Peru. Land Use Policy 49, 104-117.

Rabinow, P. (Ed.), 1984. The Foucault Reader. Pantheon Books, New York.

Radcliffe, S.A., 2012. Development for a postneoliberal era? Sumak kawsay, living well and the limits to decolonisation in Ecuador. Geoforum 43 (2), 240-249.

Rawson, A., Mansfield, B., 2018. Producing juridical knowledge: "Rights of Nature" or the naturalization of rights? Environ. Plann. E: Nat. Space 1-21. https://doi.org/10 $1177 / 2514848618763807$.

Revista Cuenca, Loma Larga es la Nueva Minería Haciendo Bien las Cosas. Published 12 April 2013. Retrieved 27 January 2018. Available at < http://www.revistacuenca. com/noticias-cuenca/LOMA-LARGA-ES-LA-NUEVA-MINERAIA-HACIENDO-BIEN LAS-COSAS $/ 58>$.

Rodriguez-de-Francisco, J.C., Boelens, R., 2015. Payment for Environmental Services: mobilising an epistemic community to construct dominant policy. Environ. Polit. 24 (3), 481-500. https://doi.org/10.1080/09644016.2015.1014658.

Sacher, W., 2017. Ofensiva Megaminera China en los Andes. Acumulación por desposesión en el Ecuador de lá Revolución Ciudadaná. Abya Yala, Quito.

Sacher, W., Acosta, A., 2012. La minería a gran escala en Ecuador. Análisis y datos estadísticos sobre la minería industrial en el Ecuador, Abya Yala, Quito.

Sanders, K., 2018. 'Beyond Human Ownership'? Property, Power and Legal Personality for Nature in Aotearoa New Zealand. J. Environ. Law 30, 2017-2234.

SCA (Sistemas Comunitarios de Agua del Azuay), 2009. Demanda de Inconstitucionalidad por la aprobación de la Ley Minera. Brought 31 March 2009. < http://www.derechoambiental.org/Derecho/Documentacion/Demanda_Grupos_Azuay_Ley_Mineria. pdf $>$.

Senplades (Planning and Development Secretariat), 2009. Plan Nacional de Desarrollo 2009-2013. Senplades, Quito.

Senplades, (Planning and Development Secretariat), 2013. Plan Nacional para el Buen Vivir 2013-2017. Senplades, Quito.

Sosa, M., Boelens, R., Zwarteveen, M., 2017. The influence of large mining: restructuring water rights among rural communities in Apurimac, Peru. Human Organiz. 76 (3), 215-226. https://doi.org/10.17730/0018-7259.76.3.215.

Stoltenborg, D., Boelens, R., 2016. Disputes over land and water rights in gold mining: the case of Cerro de San Pedro, Mexico. Water Int. 41 (3), 447-467. https://doi.org/10. 1080/02508060.2016.1143202.

Tanasescu, M., 2013. The rights of nature in Ecuador: the making of an idea. Int. J. Environ. Stud. 70 (6), 846-861.

Tanasescu, M., 2015. Nature Advocacy and the Indigenous Symbol. Environ. Values 24, 105-122.

Taylor, C., 1994. Multiculturalism. Princeton University Press.

van Teijlingen, K., 2016. The 'will to improve' at the mining frontier: neoextractivism, development and governmentality in the Ecuadorian Amazon. Extr. Ind. Soc. 3 , 902-911.

van Teijlingen, K., van, Hogenboom, B., 2016. Debating alternative development at the mining frontier: Buen Vivir and the Conflict around El Mirador Mine in Ecuador. J. Dev. Soc. 32 (4), 382-420.

Torres, N., 2015. La declaratoria del macizo del cajas como reserva de la biosfera y la minería a gran escala. Posibilidades y contradicciones en el caso de Quimsacocha, Flacso, Quito.

Urkidi, L., Walter, M., 2011. Dimensions of environmental justice in anti-gold mining movements in Latin America. Geoforum 42 (6), 683-695.

Valladares, C., Boelens, R., 2017. Extractivism and rights of nature: Governmentality, 'convenient communities' and epistemic pacts in Ecuador. Environ. Polit. 26 (6), 1015-1034. https://doi.org/10.1080/09644016.2017.1338384.

Velásquez, T., 2017. Tracing the Political Life of Kimsacocha: Conflicts over Water and Mining in Ecuador's Southern Andes. Latin Am. Perspectives. https://doi.org/10. 1177/0094582X17726088.

Veltmeyer, H., 2012. The natural resource dynamics of postneoliberalism in Latin America: new developmentalism or extractivist imperialism? Stud. Pol. Econ. 90, 75-85.

de Vos, H., Boelens, R., Bustamante, R., 2006. Formal law and local water control in the andean region: a fiercely contested field. Int. J. Water Resour. Dev. 22 (1), 37-48. 
Vos, J., Boelens, R., 2014. Sustainability Standards and the Water Question. Dev. Change 45 (2), 205-230.

Wilson, J., Bayon, M., 2017. The nature of post-neoliberalism: building bio socialism in the Ecuadorian Amazon. Geoforum 81, 55-66.

Wilson, N.J., \& Inkster, J., 2018. Respecting water: Indigenous water governance, ontologies, and the politics of kinship on the ground. Environment and Planning E: Nature and Space, online. doi: 10.1177/2514848618789378.
Wynne-Jones, S., 2012. Negotiating neoliberalism: Conservationists' role in the development of payments for ecosystem services. Geoforum 43 (6), 1035-1044.

Yashar, D.J., 2005. Contesting Citizenship in Latin America: the Rise of Indigenous Movements and the Postliberal Challenge. Cambridge University Press.

Yates, J.S., Harris, L.M., Wilson, N.J., 2017. Multiple ontologies of water: Politics, conflict and implications for governance. Environ. Plann. D: Soc. Space 35 (5), 797-815. 